\title{
Effect of Different Levels of Soil and Foliar Application of Micro-Nutrients Fertilizer on Toffahy and Balahy Indian Ber Trees (Zizyphus mauritiana Lamk) Grown in Sandy Soil
}

\author{
M.A. Amer ${ }^{1}$, Afaf M.A. Yousif ${ }^{2}$ and Adel.M.Gowda ${ }^{3}$
}

\begin{abstract}
Field experiment was conducted in seasons 2007 and 2008 on Indian ber trees (Zizyphus mauritiana Lamk) to evaluate the effect of fertilizing Toffahy and Balahy varieties with micronutrients $(\mathrm{Cu}, \mathrm{Zn}, \mathrm{Mn}$ and $\mathrm{Fe}$ ) on some vegetative and fruits characters and on leaves and fruits mineral content. Two varieties (Toffahy and Balahy), four treatments of micronutrients combinations and two methods of application (soil and foliar application) distributed randomly in a randomized block design with three replicates were used in a farm west of Alexandria, Nubaria sector. The results showed that, length of secondary shoots, total leaf chlorophyll and leaf area increased by increasing rates of application and that soil application was more pronounced than foliar one. At the same time, the dry weight of leaves did not response to either soil or foliar application of micronutrients. Moreover, Toffahy variety responded to micronutrients addition more than Balahy one. Fruit characters as height, diameter, weight, size and firmness responded significantly to micronutrients addition, while weight of seeds did not show any response to those additions. Total soluble solids (\% TSS) and acidity in the first season showed significant response to micronutrients addition, while vitamin $\mathrm{C}$ was contrary to them. DTPA- extractable $M n, Z n$ and Fe responded significantly to soil application while $\mathrm{Cu}$ showed no response. At the same time, $\mathrm{Cu}$ responded similar to $\mathrm{Zn}$ and $\mathrm{Fe}$ in leaves while $\mathrm{Mn}$ did not respond. Once again, $\mathrm{Cu}$ had not responded in fruits while the three other elements showed highly response to micronutrient additions. In all cases, soil applied micronutrients increased their concentration in leaves and fruits more than foliar application except $\mathrm{Cu}$.
\end{abstract}

\section{INTRODUCTION}

Ber or jujube belongs to the genus Zizyphus, family Rhamnaceae, which has more than 600 species (Pareek and Sharma, 1991). Of these, only a few are edible fruits such as Chinese ber ( $Z$. jujube Mill) and Indian ber $(Z$. mauritiana Lamk). They have been in cultivation since ancient times in China and India (Vashishtha, 2001).

Indian jujube ( $Z$. mauritiana Lamk) is the most common in tropical and sub-tropical regions (Obeed $e t$ al., 2008). The tree is $7-12 \mathrm{~m}$ in height and the trunk is $30 \mathrm{~cm}$ in diameter. Branches are cylinder and downy, bearing paired, brown spines, one is straight and the other is slightly hooked. The tree has a wide spreading crown and a short bole. It is ever green (Yousif, 2005) and a fast growing tree. The fruits are variable in shape and size, i.e., round, oval, or oblong. It may be yellow, green, reddish or purple / dark brown in color. The fruit length can be up to $5 \mathrm{~cm}$ and the fruit is drupe.

The tree has a deep tap root system which responds to a large number of soil types including those exposed to drought as well as water logging. Neutral slightly alkaline deep sandy soils seem to be ideal for it (Singh, 1980). Also, it tolerates moderate salinity.

Ber fruit has a high sugar content and a high level of vitamin $\mathrm{C}, \mathrm{A}$, carotene, phosphorus and calcium. The leaves contain $6 \%$ digestible crude protein. Pruned wood is used for fuel and fencing. It can produce an annual fruit yield ranging from 50 to $250 \mathrm{Kg} /$ tree. Ber fruits are very nutritious and usually eaten fresh. They can be eaten in other forms, such as dried, candied, and pickled as juice or as ber butter (Maydell, 1986).

The occurrence of adequate nutrition of plants with micronutrient cations; $\mathrm{Cu}, \mathrm{Mn}, \mathrm{Zn}$, and $\mathrm{Fe}$ depends on several factors. The ability of the soil to supply plant roots with these nutrients, mobility and translocation of these within the plant and the interaction between micronutrients themselves as with some macronutrients like phosphorus, whether in the soil and / or the plants; are factors governing nutrients balance in the plants.

Although ber tree is an economically important species, yet it does not grown in a commercial scale in Egypt and there is no fertilization program for it. So, the aim of this study is to evaluate the effect of soil and foliar application of different rates of micronutrients fertilization on vegetative growth, fruit quality and fruits and leaves mineral contents of the Indian ber grown in calcareous sandy soil in West Nubaria sector.

\footnotetext{
${ }^{1}$ Soil, Water and Environment Research Institute.

Agriculture Research Center.

${ }^{2}$ Horticulture Research Institute.

Agriculture Research Center.

${ }^{3}$ Horticulture Research Station, Seds, Horticulture Research Institute.

Agriculture Research Center

Received Febuary24, 2010, Accepted March 17, 2010
} 


\section{MATERIALS AND METHODS}

The present study was carried out during two successive seasons, 2007 and 2008 on two varieties of Indian ber, Toffahy and Balahy grown at Nubasid farm, west of Alexandria, Nubaria sector. The Indian ber orchard is grown in calcareous sandy soil. Analysis of the tested soil was given in Table (1). Ninety six trees are 12 years old, grafted on balady nabg seedlings $(Z$. spina Christi) and planted at $5 \times 5 \mathrm{~m}$ apart were selected nearly uniform in vigor growth, irrigated with drip irrigation system and received the regular horticultural managements. The received doses in the farm are $3 / 4 \mathrm{Kg}$ zinc, $1 \mathrm{Kg}$ iron, and $1 / 2 \mathrm{Kg}$ manganese in the form of sulfate dissolved in 1000 liters of water and added as foliar application per feddan once a time every year at June. The study was done in a Completely Randomized Block Design with 3 replicates. The design was applied as the following: 3 trees as replicates, two varieties (Toffahy and Balahy), 4 micronutrients concentrations, two methods of application (soil and foliar application) and two trees for each replicate.

The micronutrients were added as following:

1- The control (the farm added micronutrients).

2- $12.5 \mu \mathrm{g} / \mathrm{g}$ soil $\mathrm{Zn}, 25 \mu \mathrm{g} / \mathrm{g}$ soil Fe, $5 \mu \mathrm{g} / \mathrm{g}$ soil $\mathrm{Mn}$ and $5 \mu \mathrm{g} / \mathrm{g}$ soil $\mathrm{Cu}$.

3- $25 \mu \mathrm{g} / \mathrm{g}$ soil Zn, $50 \mu \mathrm{g} / \mathrm{g}$ soil Fe, $10 \mu \mathrm{g} / \mathrm{g}$ soil Mn and $10 \mu \mathrm{g} / \mathrm{g}$ soil $\mathrm{Cu}$.

4- $50 \mu \mathrm{g} / \mathrm{g}$ soil $\mathrm{Zn}, 75 \mu \mathrm{g} / \mathrm{g}$ soil Fe, $20 \mu \mathrm{g} / \mathrm{g}$ soil Mn and $20 \mu \mathrm{g} / \mathrm{g}$ soil $\mathrm{Cu}$.

Micronutrients were added as chelating agents either as soil application or foliar application. Each tree was sprayed or fertilized with two liters of solution containing the considerable treatment. The treatments were added two times a season in May and August.

The following characters were studied

\section{Vegetative character measurements:}

- The length of secondary shoots

The length of 10 secondary shoots per tree from full developing growth was measured $(\mathrm{cm})$.

\section{- Leaves characters measurements:}

The following parameters were measured for leaves during the two successive seasons in November:

1- A sample of 10 leaves was taken for measuring leaf area using leaf area meter (model CL-203, CID).

2- Leaf chlorophyll: the average of 10 readings was taken on the leaves of the middle of the shoots from all over the tree circumference using Minolta SPAD chlorophyll meter model (Yadava, 1986).
3- The leaves were washed with tap water, distilled water and were dried in an oven at $70^{\circ} \mathrm{C}$ to a constant weight and the dry weight was recorded.

4- The dried leaves were grounded and a sample weight of it was digested with sulfuric acid and hydrogen peroxide according to the method described by Evenhuis and DeWaard (1980). The digestion was analyzed for micronutrients $(\mathrm{Cu}, \mathrm{Mn}, \mathrm{Zn}$, and $\mathrm{Fe})$ determination by Atomic Absorption Spectrophotometer (Perkin Elmer 3300).

\section{Fruit characters measurements:}

Some fruit characters were also measured during the two successive seasons in November:

1- Ten freshly harvested fruits from each experimental tree were randomly taken to determine the average fruit dimensions (length and width, $\mathrm{cm}$ ), fruit and seed weights $(\mathrm{gm})$ and fruit size $\left(\mathrm{cm}^{3}\right)$ by water displacement.

2- Fruit firmness was determined by using pressure tester having $5 / 16$ pluger. Two readings were taken at two different positions on the flesh of each fruit after pealing.

3- In the juice of fruits, total soluble solids (TSS) were determined by using refractometer.

4- Acidity as percent citric acid and vitamin $\mathrm{C}$ content as $\mathrm{mg}$ ascorbic acid per $100 \mathrm{ml}$ juice, were determined in the juice according to (A.O.A.C., 1990 ) by titration with 0.1 sodium hydroxide and 2 , 6-dichlorophenol endophenol blue dye, respectively.

5- A part of each fruit sample was dried, digested and micronutrients were determined in as done with leaves.

\section{Characters of soil used:}

1-The used soil was analyzed for $\mathrm{pH}$, EC, soluble cations according to Richards (1954). Organic matter, $\mathrm{P}$ and $\mathrm{N}$ were determined as mentioned by Black (1965). Fe, Zn, Mn and Cu were extracted by DTPA according to Soltanpour and Schwab (1977), and measured by Atomic Absorption Spectrophotometer (Perkin Elmer 3300 model).

2- Soil samples were taken from the surface layer (0- 30 $\mathrm{cm})$ from each experimental tree for analyses. Each sample was air dried, passed from $2 \mathrm{~mm}$ sieve and extracted with DTPA (pH 7.6) and measured by Atomic Absorption Spectrophotometer (Perkin Elmer model 3300).

The data was statistically analyzed using CoStat software (1985), and presented in tables containing results of the two seasons after calculations. 


\section{RESULTS AND DISCUSSIONS}

The grown trees of Indian ber are cultivated in sandy soil which has about $32.1 \% \mathrm{CaCO}_{3}$. The soil as indicated in Table (1) refers to that it is healthy soil having low EC $\left(2 \mathrm{dS} \mathrm{m}^{-1}\right)$ and the relatively high soil $\mathrm{pH}$ is a characteristic of such soil which has high percentage of $\mathrm{CaCO}_{3}$.

Despite the use of drip irrigation system in the farm deep drains kept soil salinity at low levels. Low concentration of sodium and potassium was recognized in the soil analyses and moderately high concentration of calcium and magnesium. Low fertility of the soil was noticed $(\mathrm{O} . \mathrm{M} .=0.5)$ while the micronutrients were within the adequate levels for plants, and this may be due to the continuing planting and adding mineral fertilizers as described in the program of the farm.

\section{Vegetative character measurements:}

\section{- Leaves characters measurements:}

1- Leaf area, total Leaf chlorophyll and dry weight of leaves:

Data presented in Table (2) show the leaf area, total Leaf chlorophyll and dry weight of leaves of Indian Ber, Toffahy and Balahy., in two successive seasons 2007 and 2008.

Data indicated that, leaf area was affected significantly in the two seasons of investigation by increasing rate of micronutrient fertilizer but method of application showed no effect on it. Concerning Dry weight of leaves was not affected significantly in the first season by micronutrients treatments, while it was of highly significant in the second season. In both seasons, soil application appeared to be more efficient in increasing dry weight of leaves than foliar application and increased by increasing the rate of applied micronutrients. As for total leaf chlorophyll, it was found that it increased significantly in both seasons due to fertilization. Soil application had an evidential effect on increasing total leaf chlorophyll in the second season while it had no effect in the first season.

Total leaf chlorophyll content was almost similar in the two varieties and it ranged between 47 and 55\%.

In general, micronutrients additions as soil application was more effective than foliar application in increasing the length of secondary shoots, leaf area and total leaf chlorophyll and was not effective in increasing dry weight of leaves. Similarly, El-Sheikh et al (2008) reported that, spraying trees twice or thrice yearly was more effective than spraying one a year. They stated that the tested treatments produced a considerable increase in yield, fruit height, fruit size firmness of peach fruit as well as the content of chlorophyll a and b content. Also, Jones (1999) stated that Ziziphus species had particularly high photosynthesis rates on a unit leaf area basis in comparison with other fruit tree species, as long as there was an adequate water supply.

2- Effect of treatments on concentration of micronutrients of leaves:

Table (3) showed the effect of different treatments on the concentration of micronutrients in leaves of Indian ber trees in the two seasons.

It was noticed that added $\mathrm{Cu}$ had highly significant effect on its concentration in leaves. Both of the varieties and fertilizers application were effective significantly in the two seasons. Soil application has more effect than foliar application and Tofahy was more affected than Balahy. It was noticed also that there were no significant interaction affecting its concentration in leaves. Reith (1968) compared soil application and foliar application of $\mathrm{CuSO}_{4} .5 \mathrm{H}_{2} \mathrm{O}$ and found that foliar application was less effective than a soil application. He stated that the difference in effects on plant composition could have been due to dilution effect. Mn showed highly significant effect of fertilization on its concentration in leaves of the two varieties, but neither the varieties nor the method of application was affected by adding fertilizer. Its concentration in leaves ranged between 103 and $227 \mu \mathrm{g} / \mathrm{g}$ on leaf dry weight in the first season, but it was less in the second season where it ranged between 100 and $211 \mu \mathrm{g} / \mathrm{g}$ dry weight. It was noticed that Balahy variety had more concentration of Mn than Tofahy variety for both the two methods of applications. Zinc was noticed to affect significantly on the concentration of it in leaves. Both of the varieties and fertilizers affect significantly on its concentration in the two seasons for both of the two used varieties. Similar to $\mathrm{Cu}$ and $\mathrm{Mn}$ there were no significant interaction for the treatments on its concentration. Also, the concentration in the second season was less than that of the first season. $\mathrm{Zn}$ concentration ranged between 51 and 191 in the first season and between 52 and $185 \mu \mathrm{g} / \mathrm{g}$

\section{Table 1. The main characteristic properties of the studied soil}

\begin{tabular}{|c|c|c|c|c|c|c|c|c|c|c|c|c|c|}
\hline \multirow{2}{*}{$\begin{array}{c}E C \\
d S / m\end{array}$} & \multirow[t]{2}{*}{ pH } & \multirow{2}{*}{$\begin{array}{c}\text { Total } \\
\text { CaCo3 } \\
\% \\
\end{array}$} & \multirow{2}{*}{$\begin{array}{l}\mathbf{N} \\
\%\end{array}$} & \multirow{2}{*}{$\begin{array}{c}\mathbf{P} \\
\mu \mathrm{g} / \mathrm{g}\end{array}$} & \multirow{2}{*}{$\begin{array}{c}\text { O.M. } \\
\%\end{array}$} & \multicolumn{3}{|c|}{$\begin{array}{c}\text { soluble cations } \\
\text { meq/L }\end{array}$} & \multicolumn{5}{|c|}{$\begin{array}{l}\text { Micronutrients } \\
\quad(\mu \mathrm{g} / \mathrm{g} \text { soil })\end{array}$} \\
\hline & & & & & & $\mathrm{Ca}$ & Mg & $\mathbf{K}$ & $\mathrm{Na}$ & $\mathrm{Fe}$ & $\mathrm{Zn}$ & Mn & $\mathrm{Cu}$ \\
\hline 2.0 & 8.2 & 32.1 & 0.8 & 5.0 & 0.0 .49 & 5.4 & 3.4 & 0.3 & 11.0 & 6.5 & 2.1 & 3.7 & 0.82 \\
\hline
\end{tabular}


M.A. Amer et al., : Effect of Different Levels of Soil and Foliar Application of Micro-Nutrients Fertilizer on Toffahy and Balahy Indian ... 29 
dry weights in the second season. These results may agree with the findings of Marcelino et.al. (2005), who stated that $\mathrm{Zn}$ concentration was about $4.5 \mathrm{mg} / 100 \mathrm{~g}$. Iron was the most effect element of the treatments where it was the most concentrated one in leaves of ber. It ranged between 347.33 and $848.67 \mu \mathrm{g} / \mathrm{g}$ dry weight in the first season and between 331 and $859 \mu \mathrm{g} / \mathrm{g}$ dry weight in the second season. It had highly significant effect on its concentration in leaves as well as the effect of variety, while method of application had no effect. The greater the addition of chelating iron the greater its concentration in leaves. Benson (1976) noted that injection of $\mathrm{Fe}$ solutions into the soil for deciduous fruits had been adequate for 1 to 2 years, depending on soil conditions.

In general, the effect of treatments had the order $\mathrm{Fe}$ $>\mathrm{Cu}=\mathrm{Mn}>\mathrm{Zn}$, besides there were highly significance correlation between $\mathrm{Cu}$ in leaves and leaf area $(\mathrm{r}=0.497$ $* * *)$. The low effect of foliar application of micronutrients may be due to that foliar application must be made a number of times through the growing season because of the immobility of most of micronutrients. Ansari et.al. (2004) reported that Ziziphus vulgaris leaves contained 7.5, 67, 164, and $384 \mu \mathrm{g} / \mathrm{g}$ of $\mathrm{Zn}, \mathrm{Mn}$, $\mathrm{Cu}$ and $\mathrm{Fe}$, respectively. They found the order of concentration in leaves was as follow, $\mathrm{Fe}>\mathrm{Cu}>\mathrm{Mn}>$ $\mathrm{Zn}$. Wolley et.al. (1972) found that foliar sprays of $\mathrm{ZnSO}_{4}$ caused temporary increases in leaf $\mathrm{Zn}$ of pecan trees, besides that broadcasting the $\mathrm{Zn}$ fertilizer was more pronounced than spraying.

\section{II.-Fruits characters:}

\section{1- Physical Fruit characters:}

Table (4) showed ber fruit characters as influenced by micronutrients application.

Fruit height was affected significantly in season 2007 but was not affected in season 2008 by adding micronutrients, while the method of application showed highly significant effect in both seasons. Also fruit diameter showed the same trend in both seasons. On contrary, fruit weight did not affect either by increasing rate of applied micronutrients nor by the method of application. Consequently, the same behavior was noticed for the seed weight. Fruits size and the firmness had the same trend in having highly significant effect in the first season and weekly significant only in the second season. Soil applied micronutrients showed highly significant effect in the first season on firmness but had no effect on the second season. Size of Tofahy variety ranged between 26 and $56 \mathrm{~cm}^{3}$, while in Balahy it ranged between 24 and $58 \mathrm{~cm}^{3}$. The firmness in the second season showed high values more than in the first season. The differences between the two seasons may be due to climatic or environmental changes.

\section{2- Chemical Fruit characters:}

Table (5) refers to some chemical characters of ber fruits.

\section{Table 5:}

While \%TSS showed highly significant effect for added micronutrients, yet $\%$ acidity and vitamin $\mathrm{C}$ showed no response for adding micronutrients.

Jones (1999) found very obvious differences between cultivars of ber in fruit size, shape and flavor. Obeed et.al. (2008) tested 5 ber cultivars and found that Tofahy cultivar had the same properties as found here. Their findings as fruit weight, fruit length, fruit diameter, fruit size, seed weight, $\%$ TSS, $\%$ acidity and Vitamin C were, $31.32 \mathrm{~g}, 3.96 \mathrm{~cm}, 4.01 \mathrm{~cm}, 0.9 \mathrm{~cm}^{3}$, $1.98 \mathrm{~g}, 8.93 \%, 0.61 \%$ and $43.95 \mathrm{mg} / 100 \mathrm{ml}$, respectively.

Number of investigators found dissimilar results with different fruit trees concerning the method of application. Abd-Ella et.al. (2006) found significant difference between number and weight of fig fruits treated with micronutrients and the control. Yogaratnam \& Greenham (1982) and Ahmed et.al. (1997) reported that Anna fruits responded to foliar application of nutrients and they explained that by the stimulation of uptake by adding such nutrients by vegetative portions. Mohamed and Ahmed (1991) stated that spraying micronutrients resulted in an increase of leaf area, yield, number of fruits and fruit weight of apple fruits accompanied with an improve in the total soluble solids and reducing and total sugars and a reduction in total acidity in the pulp. Malaka et.al. (2002) found that foliar application of macronutrients was more effective on the fruits set than soil application. El-Gazzar et.al. (1971) reported similar results on Thompson seedless grapes.

\section{3- Micronutrients concentration in fruits:}

Concentration of micronutrients added $(\mathrm{Cu}, \mathrm{Mn}, \mathrm{Zn}$, and $\mathrm{Fe}$ ) in fruits of ber are shown in Table (6).

It was clear that most of them had significant effect in increasing their concentration in fruits. Copper showed no significant effect as well as varieties in the two seasons. It was clear that increasing rate of applied fertilizer increased the concentration of it in fruits' tissue. Toffahy variety was well recognized to increase in $\mathrm{Cu}$ concentration more than Balahy one when fertilizer was applied as soil application. Foliar application show slight increase and weak significant effect in the first season, while it was highly significant 
M.A. Amer et al., : Effect of Different Levels of Soil and Foliar Application of Micro-Nutrients Fertilizer on Toffahy and Balahy Indian ... 31 
M.A. Amer et al., : Effect of Different Levels of Soil and Foliar Application of Micro-Nutrients Fertilizer on Toffahy and Balahy Indian ... 33 
in the second season. The overall concentration of $\mathrm{Cu}$ did not vary during the two seasons and ranged between 3.39 and $12.22 \mu \mathrm{g} / \mathrm{g}$ dry weight fruit. The low concentration of $\mathrm{Cu}$ in fruits comparing with, its concentration in leaves indicate the low translocation from leaves to fruits where $\mathrm{Cu}$ is an immobile element in plants. As for $\mathrm{Mn}$, it had highly significant effect on both of the varieties; even the variety itself and method of application had significant effect on $\mathrm{Mn}$ concentration in fruits. Balahy variety showed more effectiveness when fertilizer was applied than foliar application as when added as soil application. Mn ranged between 9.33 and $26.11 \mu \mathrm{g} / \mathrm{g}$ dry weight fruit and there were no differences between the two years of investigation. When studying the behavior of $\mathrm{Zn}$, it showed more concentration in fruits comparing with $\mathrm{Cu}$ and $\mathrm{Mn}$. Its range was between 44.43 and $77.76 \mu \mathrm{g} / \mathrm{g}$ dry weights in the first season and between 30.55 and $55.54 \mu \mathrm{g} / \mathrm{g}$ dry weights in the second season. It was clear that the first season was more pronounced in its concentration than in the second season, moreover, in the second season micronutrient fertilizers did not show significant effect for the used treatments. As for iron, it was the most concentrated element in the fruits. It ranged between 115.33 and $291.63 \mu \mathrm{g} / \mathrm{g}$ dry weight in the first season and between 108.33 and $248 \mu \mathrm{g} / \mathrm{g}$ dry weight in the second season. The effect of adding fertilizer on Fe concentration was well pronounced in the two seasons, and on the two varieties (Toffahy and Balahy). Fe concentration increased more when fertilizer was applied as foliar application than soil application.

In spite of that, the concentrations of $\mathrm{Fe}$ gave the highest value between the measured elements, yet AlMohizea et al. (1986) reported less concentration for it where it was $1.3 \mathrm{mg} / 100 \mathrm{~g}$ and they referred that to the variety and/or to the differences in the environmental conditions that ber grown in. Jin et al. (2007) stated that $\mathrm{K}, \mathrm{P}, \mathrm{Ca}$ and $\mathrm{Mn}$ were the major mineral constituents in Chinese jujube while $\mathrm{Fe}, \mathrm{Na}, \mathrm{Zn}$ and copper were also detected in appreciable amounts. Osman and Ahmed (2009) stated that Ziziphus spina- christi was rich in Mg, $\mathrm{Ca}, \mathrm{Fe}$ and $\mathrm{Zn}$ as well as carbohydrates where as the seeds were rich in crude fiber going to that jujube fruit is good source of energy. Marcelino et al. (2005) reported that, Ziziphus sonorensis had higher level of $\mathrm{Cu}$ $(0.35 \mathrm{mg} / 100 \mathrm{~g})$, Fe $(10 \mathrm{mg} / 100 \mathrm{~g})$ and $\mathrm{Zn}(4.2 \mathrm{mg} / 100 \mathrm{~g})$. The research done by Ansari et al. (2004) found that the order of concentration of these metals in different species and medicinal plants had been found to as $\mathrm{Fe}>$ $\mathrm{Mn}>\mathrm{Zn}>\mathrm{Cu}$.

\section{III. - DTPA-extractable nutrients from soil:}

DTPA extractable $\mathrm{Cu}, \mathrm{Mn}, \mathrm{Zn}$, and $\mathrm{Fe}$ from investigated soil for both soil application and foliar application in the two seasons of growing trees are shown in Table (7).

It was clear that adding micronutrients to soil increased the extractable elements more than foliar application. The varieties and the added micronutrients had high significant effect on the level of extraction. That may mean that there was an effect to the roots of the two varieties on the DTPA extractable form. In spite of that, the method of application was not significant. On the contrary, applied $\mathrm{Zn}$ and $\mathrm{Cu}$ had poor significant effect on both of the extractable form and the varieties had no effect on the extractable form, except that $\mathrm{Zn}$ had significant effect in the second season. The extractable form of each of the micronutrients Increased with increasing rate of its application in the two forms of application. The low concentration extracted may be due to the high concentration of $\mathrm{CaCO}_{3}$ in the soil. Similar results agreed with this notification, where the presence of $\mathrm{CaCO}_{3}$ raised the $\mathrm{pH}$ of the soil. Brown (1961), stated that possibly one-third of the world's land is calcareous which is a common cause of $\mathrm{Fe}$ disorders.

Ali et al. (2009) stated that increasing lime additions to soil affected negatively the growth and mineral elements uptake of wheat but they found that adding humus limited this decrease.

\section{REFERENCES}

Abd-Ella, E; E.K, and Wafaa, A.A.Z. El-Sisi (2006). Effect of foliar applications of gibberellic acid and micronutrients on leaf mineral content, fruit set, yield and fruit quality of soltani fig trees. J. Adv. Agric. Res.

Ali V., H. Çelik, A. Turan and B. Bülent Aşik (2009).Effects of soil and foliar application of humic substances on dry weight and mineral nutrients uptake of wheat under calcareous soil conditions. Aust. J. Basic \& Appl. Sci., 3 (2): 1266- 1273.

Al-Mohizea, I.S., M.M.El-Behery and M.A.Hablass (1986). Physico-chemical characteristics of jujube fruits grown in central region of Saudi Arabia. J. Coll. Agric. King Saud Univ. 8 (2):337- 344.

Ahmed, F.F.; M.A Ragab,.; and A. A. Ahmed (1997). Efficiency of spraying boron, zinc, potassium and sulphur as affected by application of urea for anna apple trees (Malus domestica L.).Egypt. J. Hort. 24 (1): 75- 90.

Ansari, T.M.; N. Ikram; M. Najam-ul-Haq; I. Fayyaz; I. Ghafoor and N. Khalid (2004).Essential trace metal (Zinc, Manganese, Copper and Iron) levels in plants of medicinal importance. J. of Biol. Sci. 4(2): 95- 99. 
A.O.A.C. (1990). Offecial methods of analysis.The Association of official analytical chemists.Artlington, West Virginia, USA $15^{\text {th }}$ Ed. Washinton D.C.

Benson, N. R. (1976). Deciduous fruit. The micronutrient manual. Farm Tech. 23: No. 6.

Black, C.A. (1965). Methods of soil analysis. Amer. Soc. Inc. Pub., Madison, Wisconsin, USA.

Brown, J.C. (1961). Iron chlorosis in plants. Adv. Agron. 13:239- 269.

CoStat.Cohort Software (1985). Version 3.0. Tuss. Arizona.

El-Gazzar, A.M; F.M. Keleg and S.M. Sabbah (1979).Effect of foliar application of chelated iron, zinc, and manganese on yield, fruit quality, and concentrations of some nutrients in leaves of Thompson deedless grapes.Alex. J. Agric. Res. 27 (1) 28- 38.

El-Sheikh, M. H.; S. A. A. Khafagy, and N. S. Zaied (2007).Effect of foliar application with some micronutrients on leaf mineral content, yield and fruit quality of "Florida Prince and Desert Red" peach trees.Res. J. Agric. \& Biol. Sci. 3 (4): 309- 315.

Evenhuis, B. and P. W. DeWaard (1980).Principles and practices in plant analysis.FAO. Soils Bull., 38 (1): 152163.

Jin-W. L.; L. P. Fan; S. Dong and X. L. Ding (2007). Nutritional composition of five cultivars of Chinese jujube. Food Chem. 103 (2):454-460

Jones, H. G. (1999).Selection of drought tolerant fruit trees for summer rainfall regions of southern Africa and India.Summery report of European commission supported STD-3 projects.Published by CTA.

Malaka, S,M, Naiema; Ekbal Z. Ahmed and Amira A.E. ElHelaly (2002).Response of anna apple trees to foliar and soil applications of super grow, poly feed and hai leaf purple fertilizers and the physiochemical changes of the fruits during storage at room temperature. $2^{\text {nd }}$ Inter. Conf. Hort. Sci., Kafr El-Sheikh, Tanta Univ., Egypt.

Mohamed, M.A. and F.F., Ahmed (1991).Yield and quality of anna cultivar fruits as affected by application of copper, zinc and iron nutrients. Anal. of Agric. Sci., Moshtohor, 29 (1).
Marcelino, M. H.; C. L. Samuel; L. C. H. Irma; R. M. Antelmo and D. V. Francisco (2005). Physicochemical and nutritional characteristics of the fruit of Ziziphus sonorensis S. Wats. International Journal of Food Science and Nutrition 56 (8): 587- 596.

Maydell, H. (1986). Trees and shrubs for the sahel, their characteristics and uses. Deutsche Gesellschaft fur Technische Zusammenareit (GTZ). Fedral Republic of Germany, pp.400- 402.

Obeed, R. S.; M. M. Harhash and A. L. Abdel-Mawgood. ( 2008). Fruit properties and genetic diversity of five ber (Ziziphus mauritiana Lamk) cultivars.Pak. J. Biol. Sci. 11(6): 888-893.

Osman, M.A, and M.S. Ahmed (2009).Chemical and proximate composition of (Ziziphus spina-christi) nabag fruit. Nutr. and Food Sci. 39(1): 70- 75.

Pareek, O.P. and Sharma, (1991).Fruit trees for arid and semiarid lands.Indian Farming, 41:25- 33.

Reith, J. W. S. (1968). Copper deficiency in crops in northeast Scotland.J. Agr. Res. 70 (1): 39- 45.

Richards, L.S. (1954). The diagnosis and improvement of saline and alkali soils. USDA, Handbook 60.

Singh, A. (1980). Fruit physiology and production MRS. Usha Raj Kumar for Kalyani Publisher, Ludhiana.

Soltanpour, P.N. and A.P. Schwab (1977). A new soil test for simultaneous extraction of macro- and micro nutrients in alkaline soils. Comm. Soil Sci. Plant anal, 8 (3): 195- 207.

Vashishtha, B.B. (2001). Ber varieties: A monograph. Agrobios (India). Updesh Purohit for Agrobios, Jofhpur.

Wolley, R.E.; S.A. Harmon, and R.L. Carter (1972). Effect of Zinc sources and methods of application on yield and leaf mineral concentration of pecan, Carya illinoensis. J. Amer. Soc. Hort. Sci.97 (3): 364- 369.

Yadava, U. L. (1986). A rapid and non-destructive method to determine chlorophyll in intact leaves. Hort. Sci. 21: 1449- 1450.

Yogaratnam, N. and D. W. P. Greenham, (1982).The application of foliar spray containing nitrogen, magnesium, zinc and boron to apple trees. 1- Effect on fruit set and cropping.J. Hort. Sci. 57 (2) 151.

Yousif, S.M. (2005).Evaluation of five varieties of jujube fruits for their processing sutability. Annala. Agric. Sci. Moshtohor, 43 (2): 687 


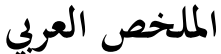

\section{تأثيرمستويات مختلفة من الأضافة الأرضية والرش بالعناصر السمادية الصغرى على أشجار العناب \\ الهندى النفاحى والبلحى النامية في أرض رملية}

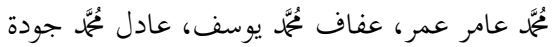

وزيادة على ذلك فأن الصنف التفاحى كان أكثر تأثرا مـن الصنف هـ البلحى و تأثر أيضا كلا من طول وقطر وحجم وصلابة الثمرة في كلا

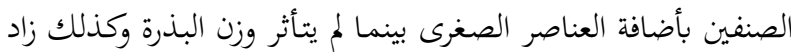
كل مـن الماده الصلبة الكلية الذائبة والحموضة بينما لم يتأثر فيتامين

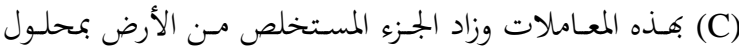
من المنجنيز والزنك والحديد زيادة معنوية بينما لم يتأثر عنصر النحاس وفن نفس الوقت فان تركيز النحاس مثل الزنك والحديد زاد في

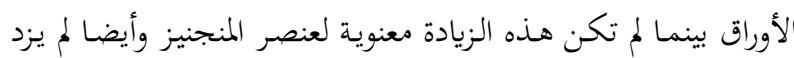
تركيز عنصر النحاس في الثمار بينما زادت الثلاث عناصر الأخرى وعلى العموم فان الأضافة الأرضية للعناصر الصغرى زادت مـن تركيز

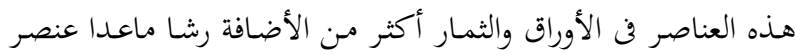
النحاس.
أجريـت بتربـة حقليـة في مـوسمى 2007، 2008 على أشجار العناب الهندى لتقييم أثر التسميد بالعناصر الصغرى (نحاس، زنك،

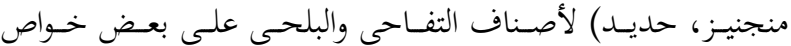

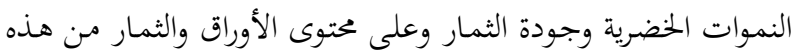

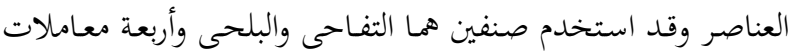

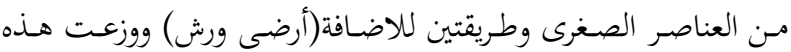
المعــاملات توزيعـا عشـوائيا في تصـميم قطاعـات عشـوائية كاملـة باستخدام ثلاث مكررات في مزرعة غرب الأسكندرية بقطاع النوبارية. وقد أظهرت النتائج زيادة كل من أطوال النموات الحديثة والكلوروفيل الكلى ومساحة الأوراق بزيادة معدل الأضافة وكانت الأضافة الأرضية

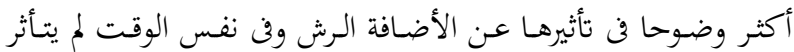

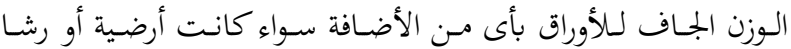

